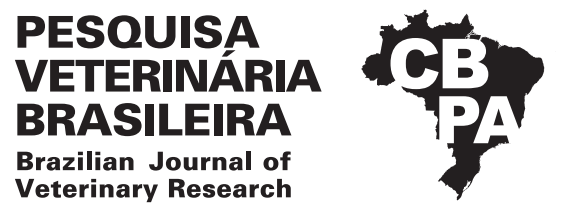

Pesq. Vet. Bras. 39(7):481-484, July 2019 DOI: $10.1590 / 1678-5150-P V B-6202$

Original Article

ISSN 0100-736X (Print) Livestock Diseases

ISSN 1678-5150 (Online)

\title{
Carrier frequency of autosomal recessive disorders (BC, BLAD, FXID and CVM) in Holstein cows in Jalisco, Mexico ${ }^{1}$
}

\begin{abstract}
Abraham Virgen-Méndez², Miguel A. Ayala-Valdovinos ${ }^{2 *}$ (D), Jorge Galindo-García², David R. Sánchez-Chiprés ${ }^{2}$, Clemente Lemus-Flores ${ }^{3}$ and Theodor Duifhuis-Rivera ${ }^{2}$

ABSTRACT.- Virgen-Méndez A., Ayala-Valdovinos M.A., Galindo-García J., Sánchez-Chiprés D.R., Lemus-Flores C. \& Duifhuis-Rivera T. 2019. Carrier frequency of autosomal recessive disorders (BC, BLAD, FXID and CVM) in Holstein cows in Jalisco, Mexico. Pesquisa Veterinária Brasileira 39(7):481-484. Departamento de Producción Animal, Centro Universitario de Ciencias Biológicas y Agropecuarias, División de Ciencias Veterinarias, Universidad de Guadalajara, Camino Ramón Padilla Sánchez 2100, Nextipac, Zapopan, Jal. C.P. 44600, Mexico. Tel: 33 36821454; E-mail: manayala@cucba.udg.mx

The hereditary autosomal recessive disorders bovine citrullinemia (BC), bovine leukocyte adhesion deficiency (BLAD), factor XI deficiency (FXID), and complex vertebral malformation (CVM) have affected dairy cattle breeding significantly around the world. This study examined the carrier frequency of BC, BLAD, FXID, and CVM autosomal recessive disorders in Bos taurus Holstein cows bred in the Altos Norte region of the state of Jalisco, Mexico. We extracted DNA from 408 random samples of peripheral blood, and then used polymerase chain reaction (PCR) to identify insertion mutations for FXID, and PCR with restriction fragment length polymorphism (PCR-RFLP) for CVM, BC and BLAD. We visualized the PCR products using agarose gel electrophoresis stained with GelRed ${ }^{\circledR}$. We found that $100 \%$ of wild-type (N/N) allele homozygous animals for genes $C D 18, A S S$, and $F X I$ were free of the mutations for BLAD, $\mathrm{BC}$ and FXID respectively. For gene $S L C 35 A 3$ we estimated total carrier frequency of $10.3 \%$ and allele frequency of $5 \%$.
\end{abstract}

INDEX TERMS: Holstein cows, genetic disease, vertebral malformation complex (CVM), factor XI deficiency (FXID), bovine citrullinemia (BC), bovine leukocyte adhesion deficiency (BLAD), Mexico, bovine.

\section{INTRODUCTION}

Overbreeding of dairy cattle from a narrow genetic base has led to undesirable effects and genetic anomalies. Animals are chosen for breeding based on potential yield without taking into account reproductive and health criteria (Cole et al. 2016). Among the most well-known recessive genetic defects in Holstein cattle are complex vertebral malformation (CVM), bovine leukocyte adhesion deficiency (BLAD), factor XI deficiency (FXID), and bovine citrullinemia (BC). These

\footnotetext{
${ }^{1}$ Received on March 15, 2019.

Accepted for publication on April 4, 2019.

2 Departamento de Producción Animal, Centro Universitario de Ciencias Biológicas y Agropecuarias, División de Ciencias Veterinarias, Universidad de Guadalajara, Camino Ramón Padilla Sánchez 2100, Nextipac, Zapopan, Jal. C. P. 44600, Mexico. Tel: 33 36821454; *Corresponding author: manayala@cucba.udg.mx

${ }^{3}$ Laboratorio de Genética Molecular, Universidad Autónoma de Nayarit, Carretera Tepic-Compostela Km 9, Xalisco, Nayarit, Mexico.
}

conditions have led to significant drops in production and economic losses (Gholap et al. 2014, Cole et al. 2016).

CVM, which is caused by a missense mutation, a single-base transversion of guanine to thymine at position 559 in the gene SLC35A3 on bovine chromosome 3 , is characterized by delayed growth, vertebral malformation, and bilateral arthrogryposis leading to premature death in calves (Agerholm et al. 2001, 2004). BLAD is characterized by impaired migration of leukocytes to infection sites and tissue lesions during immune responses (Nasreen et al. 2009). The molecular basis of BLAD is a missense mutation ( $\mathrm{A}$ to $\mathrm{G}$ ) at position 383 of the $C D 18$ gene located bovine chromosome 1 (Nagahata 2004). FXID, which is caused by a mutation of FXI gene on bovine chromosome 27, is an insertion of a 76-bp adenine-rich fragment in exon 12. This insertion, composed of an imperfect poly-adenine tract followed by a duplicated region of the normal coding sequence, introduces a premature stop codon, which impairs the synthesis of functional protein (Marron et al. 2004), is associated with excessive bleeding and reproductive problems in Holstein 
cattle (Korkmaz Ağaoğlu et al. 2015). BC, which is caused by a single-base substitution ( $\mathrm{C}$ to $\mathrm{T}$ ) at codon 86 , converting it to a nonsense codon of the gene coding of argininosuccinate synthetase ASS gene, on bovine chromosome 11 (Dennis et al. 1989), is characterized by hyperammonemia due to urea cycle interruption, which leads to neurological problems resulting ultimately in coma and death in the first week of life (Harper et al. 1986, Dennis et al. 1989).

In Mexico there are no studies on the prevalence of carriers for BC, FXID and CVM, and there is only one study on BLAD carrier frequency in the northeast region of the country (Riojas Valdés et al. 2009). Given the scarcity of information on frequency of these mutations in Holstein dairy herds in Mexico, the objective of our study was to determine the carrier frequency of genes associated with these recessive hereditary disorders in the Altos Norte region of the state of Jalisco, Mexico.

\section{MATERIALS AND METHODS}

Ethics statement. Laboratory analysis was done at the Institute of Animal Biotechnology of the University of Guadalajara, Mexico. The study was approved by Internal Bioethics Regulations of the University Center for Biological and Agricultural Sciences, University of Guadalajara, Mexico (Approval No. CC/NN11-12/00/2012).

Sample collection and DNA extraction. To calculate the size of the necessary sample, the methodology described by Fosgate (2009) was used, a total of 408 random samples were obtained from adult Holstein cows, aged between 3 and 6 years, with different physical condition and physiological state, in dairy herds of the Altos Norte region of the state of Jalisco. From each animal we collected $3 \mathrm{ml}$ of peripheral blood by caudal vein puncture into a Vacutainer ${ }^{\circledR}$ tube with EDTA. We extracted DNA from each blood sample using a Quick-DNA ${ }^{\mathrm{TM}}$ Universal Kit (Zymo Research, Orange/CA, USA).

Amplification. For PCR, we used Thermo Scientific ${ }^{\mathrm{TM}}$ PCR kits (Takara Bio Inc., Kusatsu/Shiga, Japan) with a $20 \mu$ l reaction mix containing $\sim 100$ ng blood lysate, $2 \mu \mathrm{l} \mathrm{PCR} 1 \times$ buffer with $20 \mathrm{mM} \mathrm{MgCl}_{2}$, $1 \mu \mathrm{l}$ mix of $10 \mathrm{mM}$ dNTP, $0.5 \mu$ l DreamTaq ${ }^{\circledR}$ DNA Polymerase, 5 pmol of both primers, and the remaining volume double-distilled water $\left(\mathrm{ddH}_{2} \mathrm{O}\right)$. We carried out PCRs on a Techne ${ }^{\circledR} \mathrm{TC}-5000$ Thermal Cycler (Techne Inc., Burlington/NJ, USA) using the primers and conditioners described above and shown in Table 1 , to amplify the regions of interest in SLC35A3, CD18, FXI and ASS. For the verification of the PCR-RFLP analysis, we used as a control samples, commercial semen of straws from bulls that were genotyped for these genetic diseases. We analyzed the amplification products by electrophoresis in $4 \%$ agarose gel stained with GelRed ${ }^{\mathrm{TM}}$ (Biotium, Hayward/CA, USA) and visualized the results under ultraviolet light.

Estimation of genotype and allele frequencies for each gene. To estimate genotype and allele frequencies, we applied the direct counting method described by Nei (1987).

\section{RESULTS}

In the case of CVM, we identified 42 (10.3\%) carrier cows $(\mathrm{N} / \mathrm{CVM})$ and $366(89.7 \%)$ cows free of the mutation $(\mathrm{N} / \mathrm{N})$. The homozygous mutant (CVM/CVM) was absent due to the lethal nature of the disorder and the sample type (only adult cows). Allele frequencies for CVM were 5\% with 95\% wild-type allele. We found no carrier cows for BLAD, FXID, or BC; that is, $100 \%$ of the 408 animals were homozygous for the wild-type alleles of genes related to these disorders.

\section{DISCUSSION}

Since early in the 21st century, high frequencies of CVM carrier animals have been reported in countries such as Japan, at 32.5\% (Nagahata et al. 2002), Sweden, at 23\% (Berglund et al. 2004), and Poland, at 24.8\% (Ruść \& Kamiński 2007), leading several countries to develop programs aimed at reducing CVM carrier prevalence (Ghanem et al. 2008, Ruść et al. 2013). The prevalence of carrier animals in this study was estimated at $10 \%$, was similar to that reported for Japan, at 13\% (Ghanem et al. 2008), lower than that reported for Poland, at 16.6\% (Ruść et al. 2013), and higher than in Brazil's Girolando cattle, at 1.5\% (Paiva et al. 2013).

In the 1990s, different carrier frequencies for the BLAD-associated mutation were reported in a number of countries, including USA at 14.1\% (Shuster et al. 1992), Denmark at $21.5 \%$ (Jørgensen et al. 1993), and Japan at 13.4\% (Nagahata et al. 1997). Since 2000, there has been a marked decrease in the carrier rates, such as in Iran with $3.33 \%$ (Norouzy et al. 2005), China with $1.36 \%$ (Schifferli et al. 2000), and Turkey with 2\% (Korkmaz Ağaoğlu et al. 2015). The non-incidence of BLAD carriers in our study is in agreement with reports from the Czech Republic (Citek et al. 2006) and Turkey (Oner et al. 2010).

FXID carrier frequency data have been reported in various parts of the world. In the USA, the reported frequency was 1.19\% (Marron et al. 2004), in Japan 2.5\% (Ghanem et al. 2005), in the Czech Republic 0.36\% (Citek et al. 2008). In Turkey, FXID carrier frequency studies have been conducted in diverse regions. In the Bursa region (Oner et al. 2010), carrier

Table 1. Primers used for genotyping SLC35A3, CD18, FXI and ASS mutations

\begin{tabular}{|c|c|c|c|c|c|c|c|}
\hline Gene & $\begin{array}{l}\text { Genetic } \\
\text { disorder }\end{array}$ & $\begin{array}{l}\text { Primers } \\
\left(5^{\prime}-3^{\prime}\right)\end{array}$ & $\begin{array}{l}\mathrm{Tm} \\
\left({ }^{\circ} \mathrm{C}\right)\end{array}$ & $\begin{array}{c}\text { PCR } \\
\text { product } \\
\text { (bp) }\end{array}$ & $\begin{array}{l}\text { GenBank } \\
\text { access No. }\end{array}$ & $\mathrm{RE}$ & Reference \\
\hline SLC35A3 & CVM & $\begin{array}{l}\text { F: 5'-CACAATTTGTAGGTCTCATGGCA-3' } \\
\text { R: 5'-CGATGAAAAAGGAACCAAAAGGG-3' }\end{array}$ & $54^{\circ} \mathrm{C}$ & $233 b p$ & AY160683 & Pst I & $\begin{array}{l}\text { Kanae et al. } \\
\text { (2005) }\end{array}$ \\
\hline CD18 & BLAD & $\begin{array}{l}\text { F: 5'-AGGCAGTTGCGTTCAACGTGA-3' } \\
\text { R: 5'-CCGACTCGGTGATGCCATTGA-3' }\end{array}$ & $53^{\circ} \mathrm{C}$ & $159 \mathrm{bp}$ & M81233 & Taq I & $\begin{array}{l}\text { Schifferli et al. } \\
\quad(2000)\end{array}$ \\
\hline$F X I$ & FXID & $\begin{array}{l}\text { F: 5'-CCCACTGGCTAGGAATCGTT-3' } \\
\text { R: 5'-CAAGGCAATGTCATATCCAC-3' }\end{array}$ & $54^{\circ} \mathrm{C}$ & $244 \mathrm{bp}$ & AH013749 & $\mathrm{N} / \mathrm{A}$ & $\begin{array}{l}\text { Marron et al. } \\
\text { (2004) }\end{array}$ \\
\hline$A S S$ & $\mathrm{BC}$ & $\begin{array}{l}\text { F: 5'-GGCCAGGGACCGTGTTCATTGAGGACATC-3' } \\
\text { R: 5'-TTCCTGGGACCCCGTGAGACACATACTTG-3' }\end{array}$ & $51^{\circ} \mathrm{C}$ & $185 \mathrm{bp}$ & AC000168 & Ava II & $\begin{array}{l}\text { Dennis et al. } \\
\text { (1989) }\end{array}$ \\
\hline
\end{tabular}

$\mathrm{CVM}=$ Complex vertebral malformation, BLAD = bovine leukocyte adhesion deficiency, $\mathrm{FXID}=$ factor XI deficiency, $\mathrm{BC}=$ bovine citrullinemia, $\mathrm{F}=$ forward, $\mathrm{R}=$ reverse, $\mathrm{Tm}=$ melting temperature, $\mathrm{PCR}=$ polymerase chain restriction, $\mathrm{bp}=$ base pairs, $\mathrm{RE}=$ restriction enzyme, $\mathrm{N} / \mathrm{A}=$ not applicable . 
frequency of $1.17 \%$ was found, in the Burdur region it was 1.8\% (Korkmaz Ağaoğlu et al. 2015), and in the Thrace region no FXID carriers were found (Avanus \& Ahmet 2016), as in the present study. However, for FXID, besides the number of animals sampled, the choice of random or deliberate selection criteria may also be related to the variability in FXID prevalence rates between different countries. None of these previous studies considered repeat breeding syndrome in cows as important to the selection of animals for genotyping. Thus, as suggested by Avanus \& Ahmet (2016), if future studies sample animals with this syndrome preferentially, the FXID allele frequency might increase.

The $\mathrm{BC}$ condition was reported for the first time by Healy et al. (1990) after importing semen from the US progenitor Linmack Kriss King for the Holstein population in Australia. There were subsequent reports of $\mathrm{BC}$ carrier prevalence in various countries. Whereas the reported carrier frequency in the USA was $0.3 \%$ (Robinson et al. 1993), it was $13 \%$ in Australia, the highest reported prevalence (Healy 1996). Generally, carrier frequencies are very low, as in the case of China with $0.16 \%$ (Li et al. 2011), or null as we found here, which was also reported in Germany (Grupe et al. 1996), Czech Republic (Citek et al. 2006), India (Patel et al. 2006), and Turkey (Korkmaz Ağaoğlu et al. 2015). While the FXID, BC, BLAD, and CVM related alleles have been reported in various countries, in Mexico there are no previous studies of these mutations, except a single study for BLAD (Riojas Valdés et al. 2009). In our study of 408 Holstein cows in the Altos Norte region of Jalisco for all these recessive disorders (BC, BLAD, FXID and CVM), we confirmed only the presence of CVM carriers $(10.3 \%)$. A considerable prevalence of a recessive lethal defect such as CVM could be caused by a high level of inbreeding in livestock populations, by the lack of knowledge of the possible existence of CVM by the livestock producers in cases of neonatal mortality (Ghanem \& Nishibori 2008), and by the absence of marker-assisted programs that could substantially reduce the frequency of a mutation within a little period. The different selection strategies against the lethal recessive allele in CVM are reflected in the different reduction rates of the specific allele frequencies (Schütz, et al. 2008). The absence of the mutant alleles for the genetic disorders BLAD, FXID, and BC may be due to the fact that most Holstein cattle germoplasm in Mexico is imported from the USA and Canada, where companies in charge of bovine genetics have in place selection programs to combat these hereditary diseases (Nagahata 2004) with positive effects for the cattle industry in Mexico. Despite the efforts of other countries to counteract the impact of these harmful mutations, the presence of the CVM-causing allele in our study points to insufficient planning and genetic selection of reproductive animals in Mexico.

\section{CONCLUSIONS}

In this study, we found no evidence of mutant alleles for the recessive hereditary disorders BC, BLAD, and FXID in Holstein cows in the Altos Norte region of the state of Jalisco.

For the SLC35A3 mutation associated with the hereditary CVM disorder, we calculated a mutant allele frequency at $5 \%$ and a carrier frequency at $10 \%$.

This study seems to be the first to report the allele frequency of FXID, CVM, BLAD and BC in Holstein cattle located in Jalisco, Mexico.
Acknowledgements.- This work was funded by the University of Guadalajara through project no. P3E-243948 with the support of the Institute of Animal Biotechnology belonging to the Department of Animal Production, of the University Center of Biological and Agricultural Sciences, which provided the facilities and equipment to carry out this study.

Conflict of interest statement.- The authors have no competing interests.

\section{REFERENCES}

Agerholm J.S., Bendixen C., Andersen 0. \& Arnbjerg J. 2001. Complex vertebral malformation in Holstein calves. J. Vet. Diagn. Invest. 13(4):283-289. <http://dx.doi.org/10.1177/104063870101300401><PMid:11478598>

Agerholm J.S., Bendixen C., Arnbjerg J. \& Andersen 0. 2004. Morphological variation of "complex vertebral malformation" in Holstein calves. J. Vet. Diagn. Invest. 16(6):548-553. <http://dx.doi.org/10.1177/104063870401600609> $<$ PMid:15586570>

Avanus K. \& Ahmet A. 2016. Identification of allele frequency of factor XI deficiency (FXID) in Holstein cows reared in Thrace Region of Turkey İstanbul. Ankara Univ. Vet. Fak. 42:190-193.

Berglund B., Persson A. \& Stålhammar H. 2004. Effects of complex vertebral malformation on fertility in swedish Holstein cattle. Acta Vet. Scand. 45(3/4):161-165. <http://dx.doi.org/10.1186/1751-0147-45-161> $<$ PMid:15663076>

Citek J., Rehout V., Hajkova J. \& Pavkova J. 2006. Monitoring of the genetic health of cattle in the Czech Republic. Vet. Med. 51(6):333-339. <http:// dx.doi.org/10.17221/5553-VETMED>

Citek J., Rehout V., Hanusova L. \& Vrabcova P. 2008. Sporadic incidence of factor XI deficiency in Holstein cattle. J. Sci. Food Agricult. 88(12):20692072. <http://dx.doi.org/10.1002/jsfa.3315>

Cole J.B., Null D.J. \& Vanraden P.M. 2016. Phenotypic and genetic effects of recessive haplotypes on yield, longevity, and fertility. J. Dairy Sci. 99(9):72747288. <http://dx.doi.org/10.3168/jds.2015-10777> <PMid:27394947>

Dennis J.A., Healy P.J., Beaudet A.L. \& O’Brien W.E. 1989. Molecular definition of bovine argininosuccinate synthetase deficiency. Proc. Natl Acad. Sci. 86(20):7947-7951. <http://dx.doi.org/10.1073/pnas.86.20.7947> $<$ PMid:2813370>

Fosgate G.T. 2009. Practical sample size calculations for surveillance and diagnostic investigations. J. Vet. Diagn. Invest. 21(1):3-14.<http://dx.doi. org/10.1177/104063870902100102><PMid:19139495>

Ghanem M.E. \& Nishibori M. 2008. Autosomal recessive genes in dairy cow's reproduction: incidence, consequences and future perspectives. J. Anim Genet. 36(1):53-61. <http://dx.doi.org/10.5924/abgri2000.36.53>

Ghanem M.E., Nishibori M., Nakao T., Nakatani K. \& Akita M. 2005. Factor XI mutation in a Holstein cow with repeat breeding in Japan. J. Vet. Med. Sci. 67(7):713-715.<http://dx.doi.org/10.1292/jvms.67.713><PMid:16082120>

Ghanem M.E., Akita M., Suzuki T., Kasuga A. \& Nishibori M. 2008. Complex vertebral malformation in Holstein cows in Japan and its inheritance to crossbred F1 generation. Anim. Reprod. Sci. 103(3/4):348-354. <http:// dx.doi.org/10.1016/j.anireprosci.2007.05.006> <PMid:17574783>

Gholap P.N., Kale D.S. \& Sirothia A.R. 2014. Genetic diseases in cattle: a review. Res. J. Anim. Vet. Fishery Sci. 2:24-33.

Grupe S., Dietl G. \& Schwerin M. 1996. Population survey of citrullinemia on German Holsteins. Livest. Prod. Sci. 45(1):35-38. <http://dx.doi. org/10.1016/0301-6226(95)00078-X>

Harper P.A.W., Healy P.J., Dennis J.A., O’Brien J.J. \& Rayward D.H. 1986 Citrullinemia as a cause of neurological disease in neonatal Friesian calves. Aust. Vet. J. 63(11):378-379. <http://dx.doi.org/10.1111/j.1751-0813.1986. tb02907.x><PMid:3827779> 
Healy P.J. 1996. Testing for undesirable traits in cattle: an Australian perspective. J. Anim. Sci. 74(4):917-922. <http://dx.doi.org/10.2527/1996.744917x> <PMid:8728015>

Healy P.J., Harper P.A.W. \& Dennis J.A. 1990. Bovine citrullinaemia: a clinical, pathological, biochemical and genetic study. Aust. Vet. J. 67(7):255-258. <http://dx.doi.org/10.1111/j.1751-0813.1990.tb07780.x><PMid:2393373>

Jørgensen C.B., Agerholm J., Pedersen J. \& Thomsen P.D. 1993. Bovine leukocyte adhesion deficiency in Danish Holstein-Friesian cattle: PCR-screening and allele frequency estimation. Acta Vet. Scand. 34(3):231-236. <PMid:7906090>

Kanae Y., Endoh D., Nagahata H. \& Hayashi M. 2005. A method for detecting complex vertebral malformation in Holstein calves using polymerase chain reaction - primer introduced restriction analysis. J. Vet. Diagn. Invest 17(3):258-262. <http://dx.doi.org/10.1177/104063870501700309> $<$ PMid:15945384>

Korkmaz Ağaoğlu Ö., Ağaoğlu A.R. \& Saatci M. 2015. Estimating allele frequencies of some hereditary diseases in Holstein cattle reared in Burdur Province, Turkey. Turk. J. Vet. Anim. Sci. 39:338-342. <http:// dx.doi.org/10.3906/vet-1412-13>

Li J., Wang H., Zhang Y., Hou M. \& Zhong J. 2011. Identification of BLAD and citrullinemia carriers in Chinese Holstein cattle. Anim. Sci. Pap. Rep. 29:37-42.

Marron B.M., Robinson J.L., Gentry P.A. \& Beever J.E. 2004. Identification of a mutation associated with factor XI deficiency in Holstein cattle. Anim. Genet. 35(6):454-456. <http://dx.doi.org/10.1111/j.1365-2052.2004.01202.x> $<$ PMid:15566468>

Nagahata H. 2004. Bovine leukocyte adhesion deficiency (BLAD): a review. J. Vet. Med. Sci. 66(12):1475-1482. <http://dx.doi.org/10.1292/jvms.66.1475> $<$ PMid:15644595>

Nagahata H., Miura T., Tagaki K., Ohtake M., Noda H., Yasuda T. \& Nioka K. 1997. Prevalence and allele frequency estimation of bovine leukocyte adhesion deficiency (BLAD) in Holstein-Friesian cattle in Japan. J. Vet. Med. Sci. 59(4):233-238. <http://dx.doi.org/10.1292/jvms.59.233> <PMid:9152929>

Nagahata H., Oota H., Nitanai A., Oikawa S., Higuchi H., Nakade T., Kurosawa T., Morita M. \& Ogawa H. 2002. Complex vertebral malformation in a stillborn Holstein calf in Japan. J. Vet. Med. Sci. 64(12):1107-1112. <http://dx.doi. org/10.1292/jvms.64.1107><PMid:12520102>

Nasreen F., Altaf Malik N., Naeem Riaz M. \& Anver Qureshi J. 2009. Detection and screening of bovine leukocyte adhesion deficiency in Pakistan using molecular methods. Hereditas 146(2):74-78. <http://dx.doi. org/10.1111/j.1601-5223.2009.02093.x><PMid:19490168>

Nei M. 1987. Molecular Evolutionary Genetics. Columbia University Press, New York. 512p. <http://dx.doi.org/10.7312/nei-92038>
Norouzy A., Nassiry M.R., Eftekhari Shahrody F., Javadmanesh A., Mohammad Abadi M.R. \& Sulimova G.E. 2005. Identification of bovine leucocyte adhesion deficiency (BLAD) carriers in Holstein and brown Swiss AI bulls in Iran. Russ. J. Genet. 41(12):1409-1413. <http://dx.doi.org/10.1007/s11177006-0014-7> <PMid:16396457>

Oner Y., Keskin A., Elmaci C. 2010. Identification of BLAD, DUMPS, Citrullinelmia and factor XI deficiency in Holstein cattle in Turkey. Asian J. Anim. Vet. Adv. 5(1):60-65. <http://dx.doi.org/10.3923/ajava.2010.60.65>

Paiva D.S., Fonseca I., Pinto I.S.B., Ianella P., Campos T.A., Caetano A.R., Paiva S.R., Silva M.V.G.B. \& Martins M.F. 2013. Incidence of bovine leukocyte adhesion deficiency, complex vertebral malformation, and deficiency of uridine-5-monophosphate synthase carriers in Brazilian Girolando cattle. Genet. Mol. Res. 12(3):3186-3192. <http://dx.doi.org/10.4238/2013. August.29.2><PMid:24065661>

Patel R.K., Singh K.M., Soni K.J., Chauhan J.B. \& Sambasiva Rao K.R. 2006. Lack of carriers of citrullinaemia and DUMPS in Indian Holstein cattle. J. Appl. Genet. 47(3):239-242. <http://dx.doi.org/10.1007/BF03194629> <PMid:16877802>

Riojas Valdés V.M., Carballo G.B., Rodríguez-Tovar L.E., Garza-Zermeño M.V., Ramirez-Romero R., Zárate-Ramos J. \& Dávalos Aranda G. 2009. Absence of bovine leukocyte adhesion deficiency (BLAD) in Holstein cattle from Mexico. J. Anim. Vet. Adv. 8:1870-1872.

Robinson J.L., Burns J.L., Magura C.E. \& Shanks R.D. 1993. Low incidence of Citrullinemia carriers among dairy cattle of the United States. J. Dairy. Sci. 76(3):853-858. <http://dx.doi.org/10.3168/jds.S0022-0302(93)77411$1><$ PMid:8463494>

Ruść A. \& Kamiński S. 2007. Prevalence of complex vertebral malformation carriers among Polish Holstein-Friesian bulls. J. Appl. Genet. 48(3):247-252. <http://dx.doi.org/10.1007/BF03195219><PMid:17666777>

Ruść A., Hering D., Puckowska P., Barcewicz M. \& Kamiński S. 2013. Screening of Polish Holstein-Friesian bulls towards eradication of Complex vertebral malformation (CVM) carriers. Pol. J. Vet. Sci. 16(3):579-581. <http://dx.doi. org/10.2478/pjvs-2013-0082><PMid:24195298>

Schifferli C., Laviña M.V.A. \& Villaroel M. 2000. Obtención de DNA para el estudio de BLAD en toros de Argentina y España. Arch. Zootec. 49:505-508.

Schütz E., Scharfenstein M. \& Brenig B. 2008. Implication of complex vertebral malformation and bovine leukocyte adhesion deficiency DNA-based testing on disease frequency in the Holstein population. J. Dairy Sci. 91(12):48544859. <http://dx.doi.org/10.3168/jds.2008-1154><PMid:19038961>

Shuster D.E., Kehrli Jr M.E., Ackermann M.R. \& Gilbert R.0. 1992. Identification and prevalence of a genetic defect that causes leukocyte adhesion deficiency in Holstein cattle. Proc. Natl Acad. Sci. U.S.A. 89(19):9225-9229. <http:// dx.doi.org/10.1073/pnas.89.19.9225><PMid:1384046> 